\title{
70 代健康男子の臥位運動負荷時循環特性
}

\author{
宮沢光瑞山口一郎福山はる 小田純士
}

\begin{abstract}
<要 約 > 70 代健常男 7 例に括いて，臥位運動に対する適応力，心血管反応，交感神経の果たす役割 を検討した。健常青年男20例を対照として比較に供した。自転車エルゴメータを用い，負荷は毎分50回 転で $25 \mathrm{~W}$ から開始し， 3 分毎 $25 \mathrm{~W}$ 宛漸増負荷を all out に至るまで連続的に加えた. 安静時心拍数，心 係数，一回拍出係数は両群間で有意差はなかった。動脈圧は拡張期圧には差がなかったが，収縮期圧， 脈圧は高齢群が高值であり，大動脈弾性低下を反映した。高齢群の最大負荷量平均は $75 \mathrm{~W} て ゙ ，$ 運動耐容

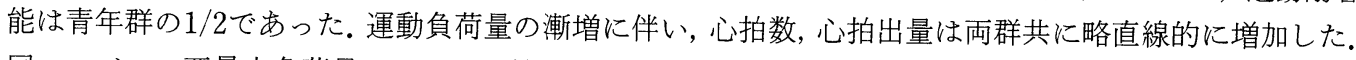
同一レベルの亜最大負荷量に打ける心拍出量を比較すると両群同じであったが，高齢群では心拍数増加 度が大, 一回拍出量増加度が小であった。一回拍出量は青年群では $75 W$ まで漸増 (30\%増加) 後略一定 となったのに対し, 高齢群では $25 \mathrm{~W} て ゙$ て安静值より $11 \%$ 増加したに過ぎなかった。この一回拍出量増加の 機序は両群共に Frank-Starling 効果によるのではなく, 心収縮能の亢進に基因した。動脈圧も負荷量と 併行して上昇したが, 最大負荷時収縮期圧, 拡張期圧は共に高齢群が高值であった。同じ拍出量下の末 梢循環反応を両群で比較すると, 高齢群は末梢血管コンダクタンスの増加度が小, 平均動脈圧の上昇度 が大であった。すなわち，抵抗血管拡張能の低下による左室後負荷増大も運動中の一回拍出量増加を抑 制する一因と解釈された。安静時血浆ノルエピネフリン濃度 (NE) は高齢群が有意に高值で, 安静時已 に交感神経機能克進状態にあることを示した。 また, 最大負荷時 NE は両群同じレベルに上昇したが, 高龄群では最大心拍数, 最大一回拍出量が低值で, 交感神経活性に対する心反応性が低下していると考 えられた。
\end{abstract}

Key words : 自転車エルゴメータ，心拍出量，左室ディメンジョン，カテコールアミン，運動耐容能。

緒

1981年の総理府統計によれば，吾国にお打る65歳以 上の人口は 1,093 万人 $(9.3 \%)$ と報ぜられている。こ のよらな人口の高齢化に伴い, 老人医療の問題が社会 保障の問題と絡んで世の関心を呼んで拉り, 予防医学 の面から老人の健康とは何かが改めて問われている。 高齢者の死因の約 $60 \%$ を占める循環器疾患は老化と深 い係わりを持って扔り, 循環系の加齢による生理的変 化を的確に把握して扔くことは極めて重要である。併 しながら，健康老人の選択が容易でないこともあり， 高齢者の運動時心血管機能に関する報告は少ない。こ のような観点から, 本文では70代健康男に打いて臥位 運動に対する適応力, 心ポンプ機能, 末梢血管系の果 たす役割を検討し, 健常青年男と比較した。

Kozui Miyazawa, Ichiro Yamaguchi, Haru Fukuyama：山形大学医学部中央検査部 Junshi Oda：小白川至誠堂病院 受付日. 1982.9. 13 .

\section{対象並びに方法}

山形市の一老人福祉施設に在籍する 70 代健康男 7 例 （70～78歳, 平均 74.0 歳)を対象とし，健常青年男 20 例 （19～37歳, 平均 26.9 歳) と対比した。健常高齢者の選 択基準は，1．心血管疾患の既往がない，2，安静時の 血圧, 心電図, 胸部 $\mathrm{X}$ 線, 肺活量, 一秒率, 血液ガス, 一般血液生化学検查値に異常所見がない, 3. 運動負荷 検査時に自他覚的異常症状がなく, 検査の目的や方法 に理解が得られたものとした。

方法は被検者をエルゴメータ付ベット上に仰臥位と し, ジェルコ・テフロン $18 \mathrm{G}$ 針を右肘静脈に, 八光ェ ラスタ $21 \mathrm{G}$ 針を右腕動脈に穿刺固定した。両足をぺダ ルに乗せ，静止した状態に約15分間保たせた後，先づ 安静時の動脈圧, 心拍出量, 左室短軸径を測定した。 動脈圧は東洋ボールドウィン社製 MPU-05-290-0-III 型 strain gauge で測定, 心拍出量はインドシアニン・ グリーン $5 \mathrm{mg}$ を右肘静脈より注入し, 虚血較正方式 earpiece densitometer (日本光電社製 MLC-4100型) 
で色素希釈曲線を記録し，Lilienfield and Kovach 法 から算出した。左室内径は心ェコー図法 (Aloka 社製 SSD-110型 Echocardiograph を使用)により求めた。 すなわち，Mモードで僧帽弁直下左室腔を記録し，拡 張及び収縮末期径を測定した，次いで心電図，動脈圧 の連続記録監視下に, Siemens-Elema 社製 380 B型工 ルゴメータを用い, 毎分50回転で25W から負荷を開始 し， 3 分毎 $25 \mathrm{~W}$ 宛漸増連続負荷を all out に至るまで 加光た。各負荷段階終了前 30 秒間に心拍出量を測定, 心エコー図を記録した。一回拍出量は心拍出量を心拍 数で除し，全末梢血管コンダクタンスは心拍出量を平 均動脈圧で除して算出した。負荷前及び最大負荷直後 飞肘静脈上り採血し, HPLC-VMD 法(柳本社製 L200 L 型-101型を使用) で血浆ノルェピネフリン $(\mathrm{NE})$ 濃 度を測定した。なお，運動負荷中の心電図に虚血性 $\mathrm{ST} ・ \mathrm{~T}$ 変化の認められたものは対象から除外した。

\section{成 績}

高齢群 7 例の安静時諸量（平均土標準誤差）を青年 群20例のそれと対比して表 1 亿示した。 心係数は両群 活涪等しく, 心拍数は青年群が大, 一回拍出係数は高 齢群が大なる傾向を有したが, 有意の差ではなかった。 動脈圧は収縮期圧, 平均圧が高齢群で高く（それぞれ $\mathrm{p}<0.01, \mathrm{p}<0.02$ ), 拡張期圧には差がなく, 大動脈壁 の弾性低下を反映した。一方, 血浆 NE 濃度は高齢群 が有意に高值で $(\mathrm{p}<0.01)$, 交感神経の緊張状態にあ ることを示した。

負荷持続時間は青年群が12.5 24.0分, 平均 17.3 分, 最大負荷量は平均 $150 \mathrm{~W}$ に達したのに対し, 高齢群で
は6.3 10.5分, 平均 8.2 分, 最大負荷量は $75 \mathrm{~W}$ と青年 群の $1 / 2$ に相当し, 加齢による運動耐容能低下が実証さ れた。

図 1 は all out 直前最大負荷時諸量の比較である. all out 時の最大心拍数は青年群の $178 \pm 2$ に対して高 齢群では $120 \pm 7 \mathrm{beats} / \mathrm{min} （$ 青年群の $2 / 3$ ）と著明低值 であった。しかし，血浆 $\mathrm{NE}$ 濃度は両群共著増して同 じレベルに達した（高齢群 $715 \pm 121 \mathrm{pg} / \mathrm{m} l$, 青年群 $702 \pm 99 \mathrm{pg} / \mathrm{m} l)$.すなわち, 高齢群では同じ交感神経活 性に対する心変時効果の減少を示した。最大負荷時の 動脈圧は収縮期圧，拡張期圧共に高齢群が高值であっ

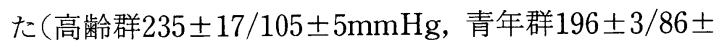
$3 \mathrm{mmHg}$ ).

心エコー図による左室拡張末期径は負荷時両群共に

表 1 安静時諸量

\begin{tabular}{|c|c|c|}
\hline & $\begin{array}{l}\text { Aged } \\
(n=7)\end{array}$ & $\begin{array}{l}\text { Young } \\
(n=20)\end{array}$ \\
\hline $\mathrm{CI}\left(1 / \mathrm{min} \cdot \mathrm{m}^{2}\right)$ & $3.53 \pm 0.38$ & $3.59 \pm 0.19$ \\
\hline HR (beats/min) & $62 \pm 4$ & $69 \pm 3$ \\
\hline $\mathrm{SI}\left(\mathrm{ml} /\right.$ beat $\left.\cdot \mathrm{m}^{2}\right)$ & $59 \pm 8$ & $52 \pm 3$ \\
\hline $\mathrm{SBP}(\mathrm{mmHg})$ & $143 \pm 3$ & $122 \pm 2 *$ \\
\hline $\mathrm{DBP}(\mathrm{mmHg})$ & $72 \pm 3$ & $74 \pm 2$ \\
\hline $\mathrm{BPm}(\mathrm{mmHg})$ & $98 \pm 2$ & $90 \pm 2 * *$ \\
\hline $\mathrm{SCI}\left(\mathrm{ml} / \mathrm{min} \cdot \mathrm{mmHg} \cdot \mathrm{m}^{2}\right)$ & $36 \pm 6$ & $40 \pm 2$ \\
\hline $\mathrm{NE}(\mathrm{pg} / \mathrm{ml})$ & $240 \pm 37$ & $159 \pm 30 *$ \\
\hline \multicolumn{3}{|c|}{ 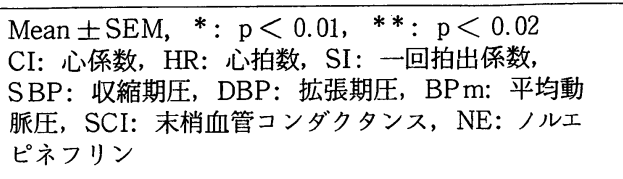 } \\
\hline
\end{tabular}
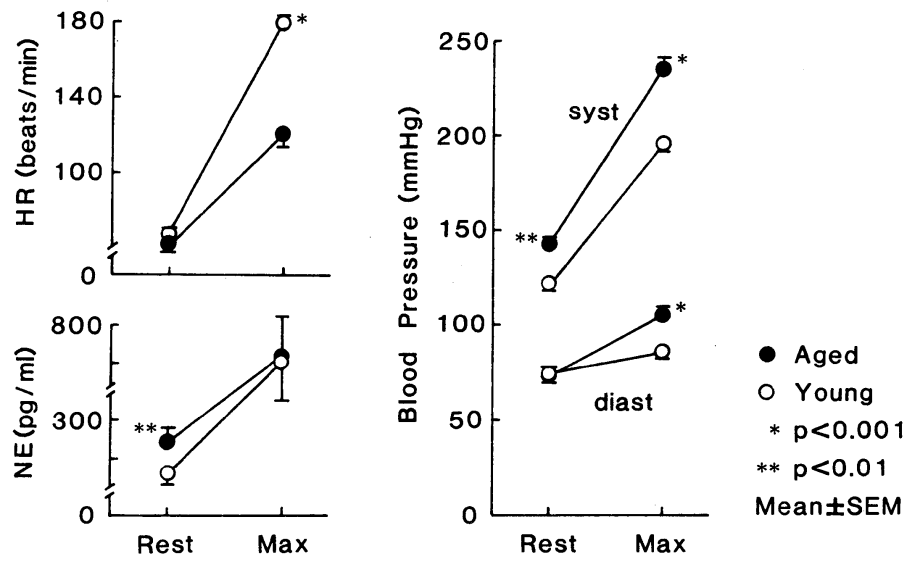

図 1 運動負荷による諸量の変化

$\mathrm{HR}$ ：心拍数, NE：ノルェピネフリン, Max：最大負荷 
不変であった(表 2 ). 収縮末期径は負荷量増加と共に 漸減したが，高齢群の減少度は青年群ほど著明ではな かった。

図 2 は負荷漸増に伴 5 心拍数, 一回拍出量, 心拍出 量の推移を示す. 前 2 者をそれぞれ縦軸, 横軸に対数 で表わすと, 両者の積である心拍出量は傾斜45度の軸 上に対数表示される。青年群では負荷量増加と共に心 拍数, 心拍出量は直線的に増加し, 一回拍出量は $75 \mathrm{~W}$ まで漸増（30\%増加）後略一定となった．亜最大同一 外部仕事 (25W, $50 \mathrm{~W}$ 負荷時) に対する心拍出量は両 群有意差はなかったが，高齢群では一回拍出量の増加 度が小さく, $25 \mathrm{~W}$ まで $11 \%$ 増加するのみで頭打ちとな り，代償的に心拍数増加が大であった。

図 3 は末梢血管コンダクタンス，平均動脈圧及び心 拍出量の関係から負荷漸増時の動態を検討した成績で ある。上述の如く，同一負荷時心拍出量は両群ほぼ同 值であったが，高齢群では同じ心拍出量に対するコン
ダクタンスの増加が小さく，代償的に平均動脈圧の上 昇が大であった。

考 察

加齢によって運動時最大心拍数, 最大心拍出量, 最 大酸素摂取量などが低下することは，健常人の経年的

表 2 運動負荷時左室短径の変化

\begin{tabular}{r|c|c|c|c}
\hline \multirow{2}{*}{} & \multicolumn{2}{|c|}{ EDD ( mm) } & \multicolumn{2}{c}{ ESD (mm) } \\
\cline { 2 - 5 } & Aged & Young & Aged & Young \\
\hline at rest & $49 \pm 2$ & $48 \pm 3$ & $32 \pm 2$ & $31 \pm 3$ \\
$25 \mathrm{~W}$ & $49 \pm 2$ & $48 \pm 3$ & $30 \pm 2$ & $29 \pm 3$ \\
$50 \mathrm{~W}$ & $49 \pm 2$ & $48 \pm 3$ & $30 \pm 2$ & $28 \pm 3$ \\
$75 \mathrm{~W}$ & & $48 \pm 3$ & & $26 \pm 3$ \\
$100 \mathrm{~W}$ & & $48 \pm 3$ & & $25 \pm 3$ \\
$125 \mathrm{~W}$ & & $47 \pm 3$ & & $24 \pm 3$ \\
\hline
\end{tabular}

EDD：拡張末期径, ESD：収縮末期径

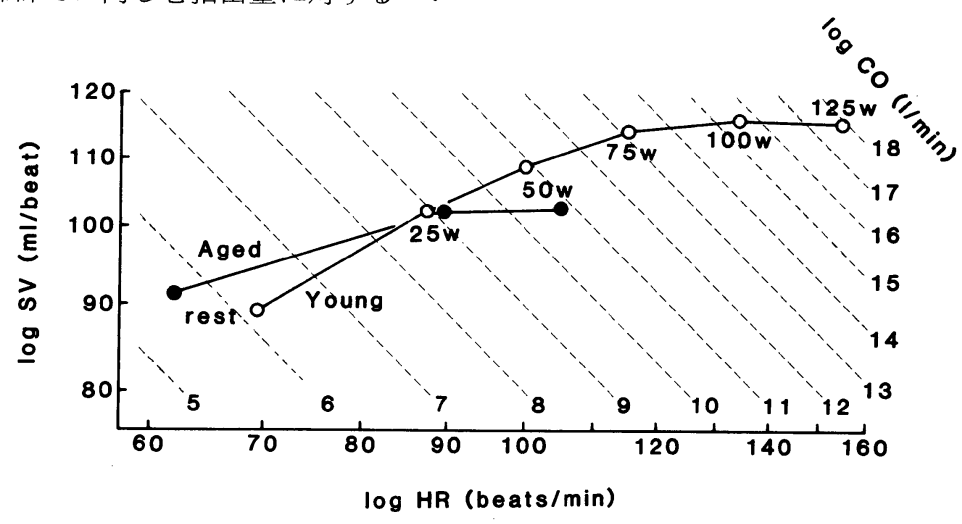

図2 負荷漸増による心拍数, 一回拍出量, 心拍出量の推移 $\mathrm{HR}$ ：心拍数, SV：一回拍出量, $\mathrm{CO}$ ：心拍出量

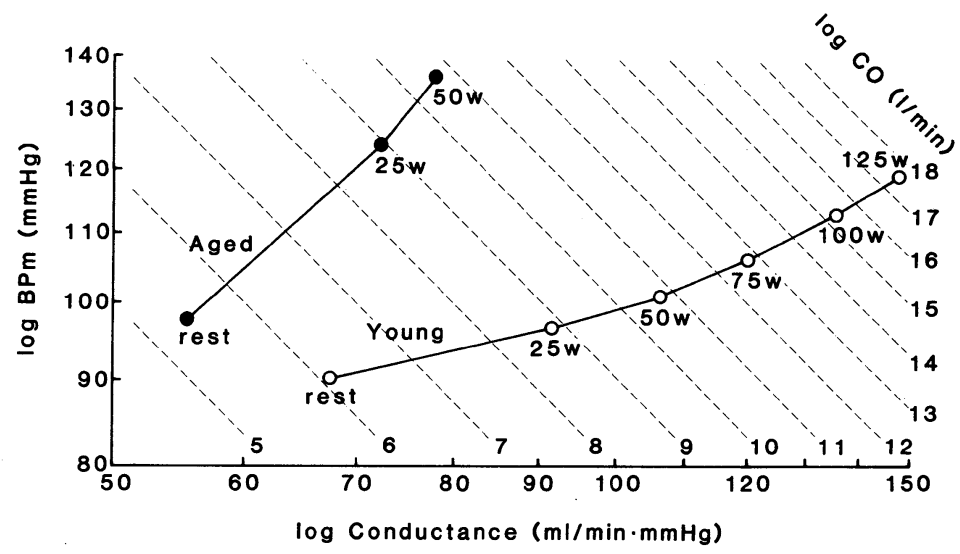

図 3 負荷漸増による末梢血管コンダクタンス, 平均動脈圧, 心拍出量の推移 $\mathrm{BPm}$ : 平均動脈圧, $\mathrm{CO}$ ：心拍出量 
検討或いは健康高齢者群と若年者群との比較から報告 されて来た ${ }^{1) 31}$. しかし, 加齢に伴う心血管機能の生理 的変化に関しては明らかでない点が甚だ多く, その理 由として, 1. 高齢者に拈ける正常心の定義が困難であ ること, 2. 従来, 心室ディメンジョンの測定には, 心 カテーテル法を必要としたため, 健常者での検査がか なり制約されたこと, 3. 心カテ施行下での運動負荷試 験は困難を伴らことなどが挙げられる、今回筆者らは 既往症, 諸検査成績, 負荷試験に対する意欲などに基 き70代健常男 7 例を選択し, 臥位, 多段階運動負荷を 試みた。実施に際しては出来るだけ非侵襲的にとの立 場から, 色素希釈法と心エコ一戝法を組合せた方法を 用いた。

前述の如く, 高齢群の最大負荷量平均は75W で, 運

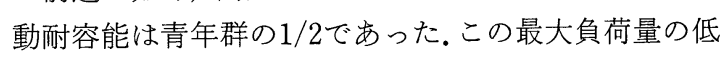
下には心血管系機能低下のほか, 多分に高齢者の非活 動的生活による影響や努力に対する意欲減退が関与し ていることも知られている ${ }^{4) 5}$. 高歯令群では, 運動耐容 能の低下に伴って最大心拍数が $120 \pm 7 \mathrm{beats} / \mathrm{min}$ と青 年群の $178 \pm 2 \mathrm{beats} / \mathrm{min}$ に比して著しく小であった. Granath ら ${ }^{6)}$ は61〜83歳の健常男16例で検討した成績 をHolmgren ら ${ }^{7)}$ の若年層のそれと比較し, 臥位最大 負荷での心拍数，心拍出量，一回拍出量がそれぞれ $17 \% ， 29 \% ， 15 \%$ 低值であったと報告している。筆者 らのプロトコールで, 被検者に最大負荷時の恒常状態 を一定時間保たせることは難かしく, 従って心拍出量 の測定は亜最大負荷に限られたが，心拍出量は負荷漸 増により両群共に直線的に増加し, 測定された最大值 は高齢群が $11.24 \pm 1.11 \mathrm{l} / \mathrm{min}$, 青年群が $19.74 \pm 1.04$ $l / \mathrm{min}$ であった.しかし, 同じレベルの負荷量に対する 心拍出量は高齢群と青年群とで差はなかった。そこで, 同じ心拍出量に対する中心循環反応を比較してみる と, 高齢群では心拍数の増加度が大, 一回拍出量増加 度が小であった。この所見は同じ亜最大負荷量におい て一回拍出量が低下し，心拍数は年龄による差がない とした Strandell ${ }^{2)}$,Weisfeldt ${ }^{8)}$ とは多少異なる成績で あった。一回拍出量は高齢群では $25 W$, 青年群では75 $\mathrm{W}$ まで漸増した後略一定であった。最大負荷時の一回 拍出量は直接測定ではないが，このような漸増負荷時 の成績からみて, 高齢群の值は青年群より小と考えら れた。

高齢群に括ける最大及び亜最大負荷時の一回拍出量 増加度の低下が, 心収縮予備能低下或いは負荷条件の 変化と如何なる関係があるかを明らかにするため，心
エコー図法により運動時左室ディメンジョンを測定し た。左室拡張末期径は表 2 の如く, 両群共に運動時不 変で, 一回拍出量増加への Frank-Starling 機序の関与 は明らかではなかった。一方, 収縮末期径が負荷量の 増加に伴い減少し, 運動時に後負荷は全例増加したこ とから, 心筋収縮能進が主役と考えられた. Port $5^{9}$ は子測最大心拍数の $85 \%$ 負荷量での駆出率をラジオア イソトープ法を用いて検討し，運動時駆出率増加は年 齢と逆相関し，前負荷や後負荷の差によるのではない と述べているが，このことも加齢による心収縮予備能 低下を示唆する。

また，収縮期動脈圧及び脈圧は安静時，運動時共に 高齢群が高值で, 加齢による大動脈弾性低下, 運動時 に括ける作業筋血管の拡張能低下を推測させた。前述 の如く, 同一心拍出量に対する末梢循環反応を両群で 比較すると, 高齢群は抵抗血管拡張能の指標である末 梢血管コンダクタンス増加度が小, 平均動脈圧の上昇 が大であった，高齢者での圧負荷が安静時よりも運動 時に著しいことは已にAbbound $5^{10)}$, Koenig $5^{11)}$, Granath $5^{6)}$ も報告しておう, 高齢者では運動時対圧 仕事量が大きく, 左室への後負荷増大も運動中の一回 拍出量増加を抑制する一因と考えられた。

交感神経活性の指標である血浆 NEは安静時には 高齢群が高く, all out 時には両群同じレベルの高值に 達した。すなわち, 高齢者は安静時交感神経緊張が亢 進し, 運動時カテコールアミン産生能は加齢によって 変化しないとの成績であった。高齢者における安静時 交感神経活性亢進については Ziegler $5^{12)}$ も已に指摘 している. 前述の筆者らの成績で, 安静時心行動は両 群差がなかったが, 高齢群では運動耐容能, 最大心拍 数, 最大一回拍出量が低值であり, このような血浆 $\mathrm{NE}$ と心行動との関係は交感神経への反応性低下の表現と 考えられた. Lakatta ら ${ }^{13)}$ はネズミでカテコールアミ ン投与による心収縮能亢進が加歯令と共に減ずることを 報告している.

以上の如く，高齢者では交感神経緊張に対する反応 性が低下し, 運動時一回拍出量の増加度減少がみられ た。その主因は心収縮予備能低下に帰せられたが，末 梢血管拡張能低下による左室後負荷増大もその一因と なることが知られ，このような生理的変化が Dock ${ }^{14)}$ のいら所謂老人心に対応するものと考えられた。老人 に拈ける心予備能低下がトレーニングによって改善も しくは抑制出来るかどらかに関しては未だ明らかでな く, 老人の健康を論ずる場合, 向後追究を要する課題 
である。

\section{結 論}

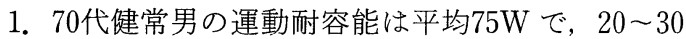

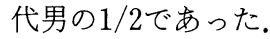

2. 同一レベルの亜最大負荷量に対する心拍出量は, 両群同じであったが，高齢群では心拍数増加度が大，

一回拍出量増加度が小であった。

3. 運動時一回拍出量増加の機序は両群共にFrank -Starling 効果ではなく，心収縮能の克進に基因した。

4. 高齢群では同じ心拍出量に㧍ける動脈圧の上昇 度が大，全末梢血管コンダクタンス増加度が小で，抵 抗血管の拡張能低下による左室後負荷増大も運動時一 回拍出量増加を抑制する一因と考えられた。

5. 最大運動負荷時交感神経活性は両群同じレベル に元進したにかかわらず, 高齢群では最大心拍数, 最 大一回拍出量が低下し, 交感神経に対する心反応性が 低下しているとの結果であった。

\section{文献}

1) Åstrand I, Åstrand P-O, Rodahl K : Maximal heart rate during work in older men. J Appl Physiol 14:562-566, 1959.

2) Strandell $T$ : Circulatory studies on healthy old men. Acta Med Scand 175(Suppl. 414) : $1-44,1964$.

3) Julius S, Amery A, Whitlock LS, Con Way J : Influence of age on the hemodynamic response to exercise. Circulation $36: 222-230,1967$.

4) Dawson PM, Hellebrandt FA: Influence of aging in man upon his capacity for physical work and upon his cardiovascular responses to exercise. Am J Physiol 143 : 420-427, 1945.

5) Raven PB, Mitchell JH : The effect of aging on the cardiovascular response to dynamic and static exercise. In Weisfeldt, ML, ed, The aging heart: Its function and response to stress. New York Raven Press, 1980, p269-296.

6) Granath A, Jonsson B, Strandell $T$ : Circulation in healthy old men, studied by right heart catheterization at rest and during exercise in supine and sitting position. Acta Med Scand 176:425-446, 1964 .

7) Holmgren A, Jonsson B, Sjöstrand T: Circulatory data in normal subjects at rest and during exercise in recumbent position, with special reference to the stroke volume at different working intensities. Acta Physiol Scand 49:343-363, 1960.

8) Weisfeldt ML: Aging of the cardiovascular system. New Eng J Med 303 : 1172-1174, 1980.

9) Port S, Cobb FR, Coleman RE, Jones RH : Effect of age on the response of the left ventricular ejection fraction to exercise. New Eng J Med 303 : 1133-1137, 1980.

10) Abbound FM, Huston JH: The effects of aging and degenerative vascular disease on the measurement of arterial rigidity in man. J Clin Invest $40: 933-939,1961$.

11) Koenig K, Reindell H, Roskamm H : Heart volume and efficiency in 60-75 year old healthy men. Arch Kreislaufforsch 39 : 143-148, 1962.

12) Ziegler MG, Lake CR, Kobin LJ : Plasma noradrenaline increases with age. Nature 261 : 333-335, 1976.

13) Lakatta EG, Gerstenblith G, Angell CS, Shock NW, Weisfeldt ML: Diminished inotropic response of aged myocardium to catecholamine. Circulation Res 36 : 262-269, 1975.

14) Dock W: How some hearts age. J A M A 195: 148-150, 1966. 
Abstract

\title{
Cardiovascular Adjustment to Exercise in the Healthy Aged
}

\author{
Kozui Miyazawa, Ichiro Yamaguchi, Haru Fukuyama and Junshi Oda*
}

Hemodynamics and plasma norepinephrine concentration (NE) at rest and during supine graded exercise were measured in 7 healthy males of 8 th decade and compared with 20 young volunteers aged 19 to 37 . Using a bicycle ergometer, exercise was started with $25 \mathrm{~W}$ and the work load was increased by $25 \mathrm{~W}$ every 3 minutes until the subject could no longer continue. At rest, the mean values of cardiac output (CO), heart rate (HR) and stroke volume (SV), and diastolic blood pressure in the aged group were not significantly different from those in the young group, while systolic blood pressure and pulse pressure were high in the aged, reflecting the decreased aortic elasticity. $\mathrm{NE}$ in the aged was significantly high under the resting state $(240 \pm 37$ vs $159 \pm 30 \mathrm{pg} / \mathrm{ml}, \mathrm{p}<0.01)$. During exercise, both $\mathrm{CO}$ and HR increased linearly with increasing work load, although maximum values were markedly lower in the aged than in the young (near-maximum CO: $11.24 \pm 1.11$ vs $19.74 \pm 1.041 / \mathrm{min}$, maximum HR: $120 \pm 7$ vs $178 \pm 2$ beats $/ \mathrm{min}, \mathrm{p}<0.001)$. However, $\mathrm{CO}$ at each stage of submaximal exercise was essentially the same in the aged as in the young, but the aged had the small increase in SV

Department of Clinical Laboratory, Yamagata University School of Medicine

Koshirakawa Shiseido Hospital* and the large increase in $\mathrm{HR}$, and the rise in blood pressure during exercise was greater in the aged than in the young, corresponding to the smaller increase in total systemic conductance (SC). An increase in SV during exercise was achieved by a greater systolic emptying and unchanged left ventricular end-diastolic dimension in the presence of increased afterload, meaning the enhanced left ventricular myocardial contractility rather than the Frank-Starling effect. A small increase in SC suggested the decreased adjustment of vascular tone in working muscles. It was considered that the reduced aortic compliance and/or small change in SC in the aged would partly play a role in a small increase in SV during exercise by inducing the marked systolic pressure load on the left ventricle. Although maximum work output in the aged was one half of that in the young (75 vs $150 \mathrm{~W}$ ) and maximum HR was markedly reduced, $\mathrm{NE}$ at exhaustion attained a similar high concentration on both groups $(715 \pm 121$ vs $702 \pm 99 \mathrm{pg} / \mathrm{ml})$. These demonstrated that the sympathetic activity during exercise remains unchanged and the cardiac response to sympathetic drive declines with advancing age.

Key words: Bicycle ergometer, cardiac output, left ventricular dimension, catecholamine, exercise capacity 